The Israeli Journal of Aquaculture - Bamidgeh, IIC:63.2011.613, 6 pages

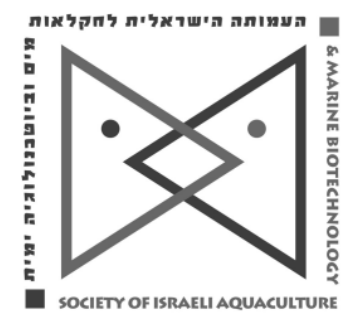

The IJA appears exclusively as a peer-reviewed on-line open access journal at http://www.siamb.org.il

Sale of IJA papers is strictly forbidden.

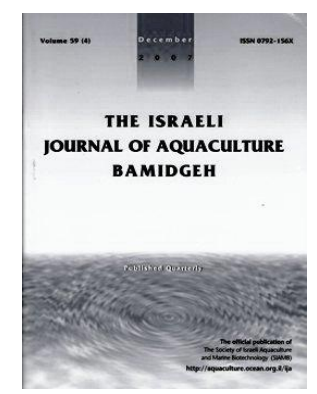

\title{
Dietary Zinc and Cobalt Requirements of Fry of Seabass (Lates calcarifer) and Catfish (Clarias batrachus)
}

\author{
P.H. Sapkale* and R.K. Singh
}

Taraporevala Marine Biological Research Station, New Administrative Building, Third Floor, Government Colony, Bandra (East), Mumbai 400051, India

(Received 23.7.10, Accepted 16.9.10)

Key words: Lates calcarifer, Clarias batrachus, cobalt, zinc, diet

\begin{abstract}
An 8-week experiment was conducted to determine the cobalt and zinc requirements of fry of seabass (Lates calcarifer) and catfish (Clarias batrachus). Fifteen diets for each fish were formulated with varying concentrations of cobalt and zinc, alone and in combination. The control diet was not supplemented with cobalt or zinc. The diets for $L$. calcarifer had $45 \%$ protein, while the diets for $C$. batrachus had $30 \%$. The diet that produced the best growth for L. calcarifer (1100\%) contained $2.5 \mathrm{mg}$ Co $+45 \mathrm{mg} \mathrm{Zn} / \mathrm{kg}$ diet and for $C$. batrachus $(1149 \%)$ contained $5 \mathrm{mg}$ Co $+30 \mathrm{mg} \mathrm{Zn} / \mathrm{kg}$. Growth in the control L. calcarifer was $738 \%$ and in the control C. batrachus was $428 \%$. For both species, the food conversion ratios were best in the above diets, $1.17 \pm 0.52$ for $L$. calcarifer and $1.40 \pm 0.62$ for $C$. batrachus as opposed to $1.89 \pm 0.39$ and $2.54 \pm 0.61$ for the respective controls.
\end{abstract}

* Corresponding author. Tel./fax: +91-22-26516816, e-mail: tmbrs@rediffmail.com 


\section{Introduction}

Enhancement of growth of fish species may be achieved by genetical manipulation or with growth promoters that improve metabolic efficiency and antioxidant enzyme activity (Wang et al., 2009). Zinc and cobalt are growth promoters in fish as they regulate enzymatic activity (Watanabe et al., 1997). Deficiency of zinc or cobalt renders poor appetite, poor growth, less synthesis of hemoglobin, erythrocyte maturation, and anemia (Hazell, 1985; Stickney, 1994).

Growth in Oreochromis niloticus, Mugil cephalus, and Liza ramada significantly increases when fed diets containing cobalt chloride (Davis and Gatlin, 1991; Hamza and Kenawy, 1997; Mahmoud, 2009). However, the dietary requirements of Co and $\mathrm{Zn}$ in freshwater fish species depend on the amount of mineral elements that exists in the surrounding water body (Hepher, 1990). Cobalt is adsorbed and desorbed to and from pond sediments (Adhikari and Ayyappan, 2002) and various water bodies have relatively high concentrations of $\mathrm{Co}$ and Zn (Kim and Paul, 2006).

Formulated diets can provide additional minerals for optimum growth of fish (Lorentzen and Maage, 1999; Jahan et al., 2000; Storebakken et al., 2000). The inclusion of cobalt in the diet of Tilapia zillii enhances the growth rate (Anadu et al., 1990; Hossien et al., 2008). The optimum dietary cobalt requirement for common carp is $0.1 \%$ (Mukherjee and Kaviraj, 2009). The zinc requirement is $20 \mathrm{mg} / \mathrm{kg}$ feed for channel catfish (Ictalurus punctatus), $15-30 \mathrm{mg} / \mathrm{kg}$ feed for common carp (Cyprinus carpio), 30 $\mathrm{mg} / \mathrm{kg}$ for rainbow trout (Salmo gairdneri; De Silva and Anderson, 1995), and $30 \mathrm{mg}$ $\mathrm{Zn} / \mathrm{kg}$ for fingerlings of tilapia (O. niloticus; Eid and Ghonim, 1994).

In this study, we examined the zinc and cobalt requirements for fry of seabass (Lates calcarifer) and catfish (Clarias batrachus), two preferred fishes for aquaculture.

\section{Materials and Methods}

Fry of seabass (Lates calcarifer) were procured from a natural seed collection center at Poynad, Raigad District, India, and acclimatized in a plastic pool (710 I) in the laboratory for one week. Fry of catfish (Clarias batrachus) were obtained from a local supplier and acclimatized in the laboratory conditions as above. During acclimatization, the fry were fed brine shrimp nauplii to satiation. At the start of the experiment, 20 fry were randomly selected and stocked into each of 48 aerated aquaria $(40.5 \mathrm{I})$. The fry were fed an artificial diet for one week before the experiment began. Sixteen $45 \%$ protein diets for seabass fry (Cuzon and Fuchs, 1988; Singh et al., 2005) and sixteen 30\% protein diets for catfish fry (Giri et al., 1999) were formulated from a basal diet (Table 1). Cobalt (Co) in the form of cobalt chloride and zinc $(\mathrm{Zn})$ in the form of zinc chloride were mixed into the diets before pelletization in varying concentrations $-2.5,5.0$, or $7.5 \mathrm{mg} \mathrm{Co} / \mathrm{kg}$ feed and $15.0,30.0$, or $45.0 \mathrm{mg} \mathrm{Zn/kg}$ feed.

Table 1. Ingredients and proximate composition of basal diets for fry of seabass (Lates calcarifer) and catfish (Clarias batrachus).

\begin{tabular}{|c|c|c|c|}
\hline \multicolumn{4}{|l|}{ Seabass } \\
\hline \multicolumn{4}{|l|}{ Ingredient (\%) } \\
\hline Fishmeal $^{1}$ & 48 & Fishmeal $^{1}$ & 40.65 \\
\hline Groundnut oil cake ${ }^{2}$ & 30 & Groundnut oil cake 2 & 26.40 \\
\hline Rice bran ${ }^{3}$ & 12 & Rice bran & 19.35 \\
\hline Bombay duck meal ${ }^{1}$ & 10 & Wheat flour & 13.60 \\
\hline \multicolumn{4}{|c|}{ Proximate composition (\%) } \\
\hline Protein & 45.00 & Protein & 30.00 \\
\hline Lipid & 8.11 & Lipid & 6.98 \\
\hline Moisture & 12.26 & Moisture & 7.55 \\
\hline Ash & 4.04 & Ash & 12.06 \\
\hline
\end{tabular}

The experiment was conducted in triplicate (15 experimental diets + one control). Feed was offered at the rate of $10 \%$ of the body weight (Singh et al., 2005) twice daily (10:00 and 16:00). Water (stored drinking water devoid of zinc and cobalt) was exchanged at a rate of $25 \%$ per day. The study was conducted for eight weeks. Percent weight gain and feed conversion ratio were determined weekly. Weight gain (\%) was computed as 100 (final wt initial wt/initial wt) and the feed conversion ratio (FCR) as wt of feed offered/wt gain (Stickney, 1994). Water temperature, dissolved oxygen, and total alkalinity were analyzed as per procedures of APHA (1998). Water $\mathrm{pH}$ 
was determined with an electronic digital $\mathrm{pH}$ meter (APX $175 \mathrm{E} / \mathrm{C}$ ).

The proximate compositions of the diets were analyzed using standard methods of AOAC (1995). Data were statistically analyzed by two-way analysis of variance (ANOVA) at $p<0.05$ (Snedecor and Cochran, 1982). Significant differences among means were examined using Duncan's multiple range test (Duncan, 1971).

\section{Results}

Water parameters are shown in Table 2. Growth and feed efficiency are shown in Table 3.

Table 2. Average physico-chemical parameters during cobalt and zinc dietary experiment.

\begin{tabular}{|c|c|c|c|c|c|c|c|c|c|}
\hline \multirow{2}{*}{ Water parameter } & \multirow{2}{*}{ Initial } & \multicolumn{8}{|c|}{ Week } \\
\hline & & 1 & 2 & 3 & 4 & 5 & 6 & 7 & 8 \\
\hline \multicolumn{10}{|l|}{ Seabass (Lates calcarifer) } \\
\hline Dissolved oxygen (mg/l) & $6.2-6.3$ & $5.8-6.0$ & $6.0-6.2$ & $6.2-6.3$ & $6.0-6.3$ & $6.1-6.2$ & $5.9-6.2$ & $5.9-6.3$ & $6.0-6.3$ \\
\hline Temperature $\left({ }^{\circ} \mathrm{C}\right)$ & 28 & 28 & 27 & 27 & 27 & 27 & 27 & 27 & 27 \\
\hline Alkalinity (mg/l) & $61-63$ & $62-63$ & $63-64$ & $63-64$ & $60-62$ & $62-63$ & $61-63$ & $62-64$ & $61-63$ \\
\hline $\mathrm{pH}$ & $7.1-7.2$ & $7.0-7.1$ & $7.2-7.3$ & $7.0-7.2$ & $7.1-7.2$ & $7.0-7.2$ & 7.1-7.3 & $7.1-7.2$ & $7.0-7.2$ \\
\hline \multicolumn{10}{|l|}{ Catfish (Clarias batrachus) } \\
\hline Dissolved oxygen (mg/l) & $6.1-6.2$ & $6.0-6.3$ & $5.8-6.0$ & $5.9-6.1$ & $6-1-6-2$ & $5.9-6.0$ & $6.0-6.1$ & $5.8-6.0$ & $6.1-6.2$ \\
\hline Temperature $\left({ }^{\circ} \mathrm{C}\right)$ & 29 & 29 & 29 & 29 & 29 & 29 & 29 & 29 & 29 \\
\hline Alkalinity (mg/l) & $60-62$ & $61-63$ & $62-64$ & $61-63$ & $61-63$ & $59-62$ & $60-62$ & $61-63$ & $59-62$ \\
\hline $\mathrm{pH}$ & $7.0-7.1$ & $7.1-7.2$ & $7.2-7.3$ & $7.1-7.2$ & $7.2-7.3$ & $7.0-7.1$ & $7.1-7.2$ & $7.0-7.1$ & $7.2-7.3$ \\
\hline
\end{tabular}

Table 3. Growth and feed conversion ratio (FCR) of fry of seabass and catfish fed diets containing different levels of cobalt (Co) and zinc ( $\mathrm{Zn})$.

\begin{tabular}{|c|c|c|c|c|c|c|c|c|}
\hline \multirow[b]{2}{*}{ Diet } & \multicolumn{4}{|c|}{ Sea bass } & \multicolumn{4}{|c|}{ Catfish } \\
\hline & $\begin{array}{l}\text { Initial } \\
\text { wt }(g)\end{array}$ & $\begin{array}{l}\text { Final } \\
w t(g)\end{array}$ & $\begin{array}{c}W t \\
\text { gain } \\
(\%)\end{array}$ & $F C R$ & $\begin{array}{l}\text { Initial } \\
w t(g)\end{array}$ & $\begin{array}{l}\text { Final } \\
w t(g)\end{array}$ & $\begin{array}{l}\text { Wt } \\
\text { gain } \\
(\%)\end{array}$ & $F C R$ \\
\hline Control & $0.24 \pm 0.01$ & $2.01 \pm 0.17^{\mathrm{a}}$ & 738 & $1.89 \pm 0.39^{\mathrm{a}}$ & $0.50 \pm 0.06$ & $2.67 \pm 0.38^{\mathrm{a}}$ & 428 & $2.54 \pm 0.61^{\mathrm{a}}$ \\
\hline $2.5 \mathrm{mg} \mathrm{Co}$ & $0.24 \pm 0.02$ & $2.31 \pm 0.36^{\mathrm{b}}$ & 863 & $1.47 \pm 0.16^{\mathrm{b}}$ & $0.50 \pm 0.08$ & $3.12 \pm 0.14^{\mathrm{b}}$ & 517 & $1.77 \pm 0.15^{\mathrm{b}}$ \\
\hline $5.0 \mathrm{mg} \mathrm{Co}$ & $0.24 \pm 0.04$ & $2.27 \pm 0.19^{b}$ & 846 & $1.53 \pm 0.14^{c}$ & $0.50 \pm 0.01$ & $3.87 \pm 0.36^{c}$ & 665 & $1.86 \pm 0.37^{c}$ \\
\hline $7.5 \mathrm{mg} \mathrm{Co}$ & $0.24 \pm 0.03$ & $2.14 \pm 0.47^{c}$ & 792 & $1.51 \pm 0.72^{c}$ & $0.50 \pm 0.05$ & $4.10 \pm 0.54^{d}$ & 712 & $1.93 \pm 0.42^{\mathrm{d}}$ \\
\hline 15 mg Zn & $0.24 \pm 0.06$ & $2.17 \pm 0.83^{c}$ & 804 & $1.35 \pm 0.11^{\mathrm{d}}$ & $0.50 \pm 0.03$ & $3.28 \pm 0.73^{\mathrm{b}}$ & 550 & $1.84 \pm 0.31^{\mathrm{c}}$ \\
\hline 30 mg Zn & $0.24 \pm 0.03$ & $2.19 \pm 0.16^{c}$ & 813 & $1.78 \pm 0.69^{\mathrm{e}}$ & $0.50 \pm 0.03$ & $4.93 \pm 0.11^{\mathrm{e}}$ & 876 & $1.67 \pm 0.74^{\mathrm{e}}$ \\
\hline $45 \mathrm{mg} \mathrm{Zn}$ & $0.24 \pm 0.07$ & $2.52 \pm 0.11^{d}$ & 950 & $1.59 \pm 0.40^{f}$ & $0.50 \pm 0.09$ & $5.11 \pm 1.36^{f}$ & 911 & $1.94 \pm 0.60^{d}$ \\
\hline $2.5 \mathrm{Co}+15 \mathrm{mg} \mathrm{Zn}$ & $0.24 \pm 0.05$ & $2.49 \pm 0.38^{d}$ & 938 & $1.68 \pm 0.97^{9}$ & $0.50 \pm 0.07$ & $3.38 \pm 0.71^{\mathrm{b}}$ & 568 & $1.81 \pm 0.48^{c}$ \\
\hline $2.5 \mathrm{Co}+30 \mathrm{mg} \mathrm{Zn}$ & $0.24 \pm 0.08$ & $2.37 \pm 0.51^{b}$ & 888 & $1.50 \pm 0.63^{c}$ & $0.50 \pm 0.03$ & $5.80 \pm 0.32^{9}$ & 1047 & $1.49 \pm 0.71^{f}$ \\
\hline $2.5 \mathrm{Co}+45 \mathrm{mg} \mathrm{Zn}$ & $0.24 \pm 0.03$ & $2.88 \pm 0.64^{e}$ & 1100 & $1.17 \pm 0.52^{\mathrm{h}}$ & $0.50 \pm 0.06$ & $5.47 \pm 0.22^{9}$ & 981 & $1.76 \pm 0.82^{b}$ \\
\hline $5.0 \mathrm{Co}+15 \mathrm{mg} \mathrm{Zn}$ & $0.24 \pm 0.02$ & $2.62 \pm 0.19^{d}$ & 992 & $1.35 \pm 0.14^{\mathrm{d}}$ & $0.50 \pm 0.06$ & $3.99 \pm 0.21^{\mathrm{c}}$ & 690 & $1.83 \pm 0.17^{c}$ \\
\hline $5.0 \mathrm{Co}+30 \mathrm{mg} \mathrm{Zn}$ & $0.24 \pm 0.07$ & $2.58 \pm 0.32^{d}$ & 975 & $1.58 \pm 0.10^{f}$ & $0.50 \pm 0.03$ & $6.32 \pm 0.73^{h}$ & 1149 & $1.40 \pm 0.62^{f}$ \\
\hline $5.0 \mathrm{Co}+45 \mathrm{mg} \mathrm{Zn}$ & $0.24 \pm 0.01$ & $2.71 \pm 0.69^{f}$ & 1029 & $1.22 \pm 0.36^{\mathrm{h}}$ & $0.50 \pm 0.02$ & $5.89 \pm 0.66^{9}$ & 1064 & $1.58 \pm 0.30^{9}$ \\
\hline $7.5 \mathrm{Co}+15 \mathrm{mg} \mathrm{Zn}$ & $0.24 \pm 0.06$ & $2.49 \pm 0.17^{d}$ & 938 & $1.78 \pm 0.78^{\mathrm{e}}$ & $0.50 \pm 0.07$ & $3.19 \pm 0.14^{\mathrm{b}}$ & 531 & $1.83 \pm 0.12^{\mathrm{c}}$ \\
\hline $7.5 \mathrm{Co}+30 \mathrm{mg} \mathrm{Zn}$ & $0.24 \pm 0.06$ & $2.55 \pm 0.18^{d}$ & 963 & $1.84 \pm 0.49^{\mathrm{a}}$ & $0.50 \pm 0.01$ & $3.91 \pm 0.73^{c}$ & 674 & $1.71 \pm 0.59^{b}$ \\
\hline $7.5 \mathrm{Co}+45 \mathrm{mg} \mathrm{Zn}$ & $0.24 \pm 0.01$ & $2.57 \pm 0.63^{d}$ & 970 & $1.70 \pm 0.83^{9}$ & $0.50 \pm 0.08$ & $3.87 \pm 0.61^{c}$ & 665 & $1.69 \pm 0.71^{\mathrm{e}}$ \\
\hline
\end{tabular}

Means in a column identified by different superscripts significantly differ $(p<0.05)$.

\section{Discussion}

The weight of both $L$. calcarifer and C. batrachus increased significantly in all the treatments as compared to the control. Percent weight gain was much higher in treatments containing both cobalt and zinc. Similar results were recorded for fry of Osteobrama belangeri (Azad, 1997) and O. niloticus (Mahmoud, 2009), suggesting that feed intake and, thereby, weight gain are influenced by levels of cobalt and zinc, which play a role in enzymatic activities involved in metabolic and biochemical processes in the body (Dabrowski et al., 1993; Guillaume et al., 2001). Dietary cobalt and zinc stimulate oxygen chemoreceptors and hypoxic reflexes (Maage and Julshamn, 1993; Apines et al., 
2001; Tan and Mai, 2001). The differences in Co and Zn requirements of $L$. calcarifer and C. batrachus could be attributed to differences in their metabolic rates, feeding habits, age, sex, and species (Kotze et al., 1999). The best FCR was achieved with the $2.5 \mathrm{mg}$ Co+45 mg Zn diet for L. calcarifer and the $5 \mathrm{mg} \mathrm{Co}+30 \mathrm{mg} \mathrm{Zn}$ diet for C. batrachus. Likewise, in $O$. belangeri, the best FCR was achieved by fry fed a diet containing $5 \mathrm{ppm}$ Co+45 ppm Zn (Azad, 1997). Juvenile Atlantic salmon fed a diet containing $100 \mathrm{mg}$ $\mathrm{Zn} / \mathrm{kg}$ had a good growth rate but feed conversion efficiency dropped from 1.02 to 0.89\% (Shearer et al., 1992).

The zinc requirement of carp ranges $15-30 \mathrm{mg} \mathrm{Zn/kg} \mathrm{(Gatlin} \mathrm{and} \mathrm{Wilson,} \mathrm{1983).} \mathrm{High}$ dietary concentrations of $\mathrm{Zn}$ and Co accumulated in body tissues when a diet containing $2000 \mathrm{mg} \mathrm{Zn/kg}$ diet was fed to common carp (C. carpio), grass carp (Ctenopharyngodon idellus), and tilapia (Oreochromis aureus) for eight weeks and dropped when the concentration was reduced to $50 \mathrm{mg} \mathrm{Zn/kg}$ diet (Sun and Jeng, 1999). Also, accumulated $\mathrm{Zn}$ in the digestive tract tissues of common carp decreased when the dietary $\mathrm{Zn}$ was reduced to a normal $(50 \mathrm{mg} / \mathrm{kg}$ ) or deficient $(4 \mathrm{mg} / \mathrm{kg}$ ) level for four weeks (Sun and Jeng, 1999).

Fingerling Nile tilapia fed a diet supplemented with $30 \mathrm{mg} \mathrm{Zn/kg} \mathrm{showed} \mathrm{better}$ growth than those fed a diet containing $5 \mathrm{mg} \mathrm{Zn/kg} \mathrm{(Eid} \mathrm{and} \mathrm{Ghonim,} \mathrm{1994).} \mathrm{The}$ optimum level of zinc $(44.50 \mathrm{mg} / \mathrm{kg}$ diet) improved the weight gain of juvenile $O$. niloticus (do Carmo e Sa et al., 2004) while a higher weight gain and feed efficiency was obtained in Epinephelus malabaricus fed diets containing 10.7 and $20.7 \mathrm{mg} \mathrm{Co} / \mathrm{kg}$ (Lin et al., 2010). Fish living in contaminated sediments, water, or biotic communities, accumulate metals in their body (Shahunthala, 1989; McCarthy and Shugart, 1996; Jezierska and Witesta, 2001). In the present investigation, Zn levels were low.

In conclusion, the $2.5 \mathrm{mg} \mathrm{Co}+45 \mathrm{mg} \mathrm{Zn} / \mathrm{kg}$ diet promoted the best growth in $L$. calcarifer fry and the $5 \mathrm{mg} \mathrm{Co}+30 \mathrm{mg} \mathrm{Zn} / \mathrm{kg}$ diet maximized growth in C. batrachus fry grown in freshwater culture using cobalt and zinc deficient water.

\section{References}

Adhikari S. and S. Ayyappan, 2002. Fertilization of freshwater fish ponds with cobalt and its adsorption and desorption in the pond sediment. Isr. J. Aquacult. - Bamidgeh, 54(3):110-115.

Anadu D.I., Anozie O.C. and A.D. Anthony, 1990. Growth responses of Tilapia zilli fed diets containing various levels of ascorbic acid and cobalt chloride. Aquaculture, 88:329336.

AOAC, 1995. Official Methods of Analysis. Assoc. Official Analytical Chemists, Arlington, VA. $684 \mathrm{pp}$.

APHA, 1998. Standard Methods for the Examination of Water and Waste Water, $16^{\text {th }}$ ed. APHA, AWWA, WPFC, NY.

Apines M.J., Satoh S., Kiron V., Watanabe T., Nasu N. and S. Fugita, 2001. Bioavailability of amino acid chelated and glass embaded zinc to rainbow trout, Oncorhynchus mykiss, fingerlings. Aquacult. Nutr., 7:221-228.

Azad I.S., 1997. Growth performance of advanced fry of Pengba Osteobrama belangeri (Val.) fed with cobalt and zinc supplemented diets. J. Aquacult. Trop., 12(2):133-138.

Cuzon G. and J. Fuchs, 1988. Preliminary nutritional studies of seabass Lates calcarifer (Bloch), protein and lipid requirements. pp. 15-16. In: Program and Abstracts, $19^{\text {th }}$ Annual Conference and Exposition. World Aquaculture Society, Hawaii.

Dabrowski K., Moreau K. and D.K. El-Saidy, 1993. Ontogenetic sensitivity of channel catfish to ascorbic acid deficiency. J. Aquat. Anim. Health, 8:22-27.

Davis A.D. and D.M. Gatlin III, 1991. Dietary mineral requirements of fish and shrimp. pp. 49-67. In: D.M. Akiyama, K.H. Tan (eds.). Proc. Aquaculture Feed Processing and Nutrition Workshop. Am. Soybean Assoc., Singapore.

De Silva S.S. and T.A. Anderson, 1995. Fish Nutrition in Aquaculture, $1^{\text {st }}$ ed. Chapman and Hall, London. 309 pp. 
do Carmo e Sa M.V., Pezzato L.E., Barros Ferreira Lima M.M. and P. de Magalhães Padilha, 2004. Optimum zinc supplementation level in Nile tilapia, Oreochromis niloticus juveniles diets. Aquaculture, 238:385-401.

Duncan D.B., 1971. Multiple range and multiple F-tests. Biometrics, 11:1-42.

Eid A.E. and S.I. Ghonim, 1994. Dietary zinc requirement of fingerling of Oreochromis niloticus. Aquaculture, 119:259-264.

Gatlin III D.M. and R.P. Wilson, 1983. Dietary zinc requirement of fingerling channel catfish. J. Nutr., 113(3):630-635.

Giri S.S., Sahoo S.K., Sahu A.K. and P.K. Mukhopadhyay, 1999. Growth, feed utilization and carcass composition of Clarias batrachus (Linn.) fingerlings fed on dried fish and chicken viscera incorporated diets. Aquacult. Res., 31:767-771.

Guillaume J., Kaushik S., Bergot P. and R. Metailler, 2001. Nutrition and Feeding of Fish and Crustaceans, $1^{\text {st }}$ ed. Chichester, UK. 403 pp.

Hamza A.K. and S.M. Kenawy, 1997. Effect of growth promoting materials on survival and growth rates of mullet fish fry Mugil cephalus and Liza ramada. Bull. Fac. Sci., Zagazig Univ., 19(1):267-273.

Hazell T., 1985. Minerals in foods: dietary sources, chemical forms, interactions, bioavailability. World Rev. Nutr. Diet., 46:1-123.

Hepher B., 1990. Nutrition of Pond Fishes. Cambridge Univ. Press, Cambridge, UK.

Hossien E., Abbas M. and B. Shohreh, 2008. Effects of cobalt as growth promotant on the growth of rainbow trout, Oncorhynchus mykiss. World Aquaculture 2008: Aquaculture for Human Wellbeing - The Asian Perspective. Busan, Korea. 165 pp.

Jahan P., Watanabe T., Satoh S. and V. Kiron, 2000. Effect of dietary fish meal levels on environmental phosphorous loading from carp culture. Fish. Sci., 66:204-210.

Jezierska B. and M. Witesta, 2001. The Metal Uptake and Accumulation in Fish Living in Polluted Waters. Dept. Anim. Physiol., Univ. Podlasie, Prusa 12, 08-110 Siedlce, Poland. $107 \mathrm{pp}$.

Kim J.H. and D.H. Paul, 2006. Cobalt and Inorganic Cobalt Compounds. Concise Int. Chemical Assessment Document 69. World Health Organization, Geneva.

Kotze P., du Preez H.H. and J.H.J. van Vuren, 1999. Bioaccumulation of copper and zinc in Oreochromis mossambicus and Clarias gariepinus from the Olifants River, Mpumalanga, South Africa. Water S.A., 25:99-110.

Lin Y.H., Wu J.Y. and S.Y. Shiau, 2010. Dietary cobalt can promote gastrointestinal bacterial production of vitamin B12 in sufficient amounts to supply growth requirements of grouper, Epinephelus malabaricus. Aquaculture, 302:89-93.

Lorentzen M. and A. Maage, 1999. Trace element status of juvenile Atlantic salmon Salmo salar L. fed a fishmeal based diet with or without supplementation of zinc, iron, manganese and copper from first feeding. Aquacult. Nutr., 5:163-171.

Maage A. and K. Julshamn, 1993. Assessment of zinc status in juvenile Atlantic salmon (Salmo salar) by measurement of whole body and tissue levels of zinc. Aquaculture, 117:179-191.

Mahmoud S.A., 2009. Effect of different artificial diets on growth rate condition and histological structure of Nile tilapia (Oreochromis niloticus). Res. J. Fish. Hydrobiol., 4(1): 29-34.

McCarthy J.F. and L.R. Shugart, 1996. Biomarkers of Environmental Contamination. Lewis Pub., NY. 425 pp.

Mukherjee S. and A. Kaviraj, 2009. Evaluation of growth and bioaccumulation of cobalt in different tissues of common carp, Cyprinus carpio (Actinopterygii: Cypriniformes: Cyprinidae), fed cobalt-supplemented diets. Acta Ichthyol. Pisc., 39(2):87-93.

Shahunthala D., 1989. Heavy metal levels in Malaysian fish. Fish. Bull., 58:3-6.

Shearer K.D., Maage A., Opstvedt J. and H. Mundheim, 1992. Effects of high-ash diets on growth, feed efficiency and zinc status of juvenile Atlantic salmon (Salmo salar). Aquaculture, 106:45-355. 
Singh R.K., Vartak V. and A. Balange, 2005. Effect of stimulants on feeding response, feeding behavior, and growth of fry of sea bass, Lates calcarifer (Bloch, 1970). Isr. J. Aquacult. - Bamidgeh, 57(1):32-38.

Snedecor G.W. and W.G. Cochran, 1982. Statistical Methods. Iowa State Univ. Press, Ames, Iowa. 507 pp.

Stickney R.R., 1994. Principles of Aquaculture. John Wiley and Sons, NY. 485 pp.

Storebakken T., Shearer K.D. and A.J. Roem, 2000. Growth, uptake and retention of nitrogen and phosphorus and absorption of other minerals in Atlantic salmon Salmo salar fed diets with fish meal and soy-protein concentrate as the main sources of protein. Aquacult. Nutr., 6:103-108.

Sun L.T. and S.S. Jeng, 1999. Accumulation of zinc from diet and its release in common carp. Fish Physiol. Biochem., 20:313-324.

Tan B. and K. Mai, 2001. Zinc methionine and zinc sulfate as sources of dietary zinc for juvenile abalone, Haliotis discus hannai Ino. Aquaculture, 192:67-84.

Wang H.W., Cai D.B., Xiao G.H., Zhao C.L., Wang Z.H., Xu H.M. and Y.Q. Guan, 2009. Effects of selenium on the activity of antioxidant enzymes in the shrimp, Neocaridina heteropoda. Isr. J. Aquacult. - Bamidgeh, 61(4):322-329.

Watanabe T., Kiron V. and S. Satoh, 1997. Trace minerals in fish nutrition. Aquaculture, 151:185-207. 